\title{
Construction of a shuttle expression vector for lactic acid bacteria
}

\author{
Tejinder Kaur ${ }^{*}$ (D), Praveen P. Balgir and Baljinder Kaur
}

\begin{abstract}
Background: Lactic acid bacteria (LAB) are a diverse group of Gram-positive bacteria, which are widely distributed in various diverse natural habitats. These are used in a variety of industrial food fermentations and carry numerous traits with utmost relevance to the food industry. Genetic engineering has emerged as an effective means to improve and enhance the potential of commercially important bacterial strains. However, the biosafety of recombinant systems is an important concern during the implementation of such technologies on an industrial scale. In order to overcome this issue, cloning and expression systems have been developed preferably from fully characterized and annotated LAB plasmids encoding genes with known functions.

Results: The developed shuttle vector PPBT-GFP contains two theta-type replicons with a copy number of 4.4 and 2.8 in Pediococcus acidilactici MTCC 5101 and Lactobacillus brevis MTCC 1750, respectively. Antimicrobial "pediocin" produced by P. acidilactici MTCC 5101 and green fluorescent protein (GFP) of Aequorea victoria were successfully expressed as selectable markers. Heterologous bile salt hydrolase (BSH) from Lactobacillus fermentum NCDO 394 has been efficiently expressed in the host strains showing high specific activity of $126.12 \pm 10.62$ in P. acidilactici MTCC 5101 and $95.43 \pm 4.26$ in the case of L. brevis MTCC 1750, towards glycine-conjugated bile salts preferably as compared to taurine-conjugated salts.

Conclusion: The present article details the development of a LAB/LAB shuttle expression vector pPBT-GFP, capable of replication in LAB hosts, P. acidilactici MTCC 5101, and L. brevis MTCC 1750. Pediocin and GFP have been used as selectable markers with the efficient production of heterologous extracellular bile salt hydrolase. Thus, the constructed vector PPBT-GFP, with its ability to replicate in multiple hosts, low copy number, and stability in host cells, may serve as an ideal tool for improving $L A B$ strains of commercial value using genetic engineering.
\end{abstract}

Keywords: Lactic acid bacteria, Plasmid vector, Expression vector, Heterologous gene expression, Green fluorescent protein, Bile salt hydrolase

\section{Background}

Lactic acid bacteria (LAB) are historically defined as a heterogeneous group of Gram-positive, microaerophilic, non-sporulating, and low $\mathrm{G}+\mathrm{C}$ microorganisms that ferment hexose sugars to primarily produce lactic acid. This functional classification includes a variety of industrially important genera, including Enterococcus, Lactobacillus, Lactococcus, Leuconostoc, Oenococcus, Pediococcus, and Streptococcus species [1]. These bacteria are commonly found in diverse natural habitats and are used in commercial production of a variety of fermented food products, macromolecules, enzymes, and

* Correspondence: tejinder.kaur.6@gmail.com

Department of Biotechnology, Punjabi University, Patiala 147002, India metabolites [2-4]. The seemingly simplistic metabolism of LAB has been exploited throughout history, for value addition and preservation of foods and beverages in nearly all societies, dating back to the origins of agriculture [5]. Nowadays, LAB have gained significant importance as probiotics, which when consumed aid in the regulation of microflora present in the human gut. In order to widen industrial applications of LAB, an effective way is to improve strain characteristics using genetic engineering techniques. Worldwide research is focused on finding ways to enhance heterologous expression of foreign proteins in the LAB. Plasmids present in LABs provide the opportunity to derive vectors which can be used for various purposes like gene knockouts, 
amplification, substitution, insertion, multiplication, and expression of heterologous proteins.

For further industrial level applications of such processes, various strategies like the use of high-copy number plasmid vectors, strong constitutive promoter, regulated strong promoters, and extracellular secretion along with scale up are being developed [6]. The genetically enhanced LABs need to be checked for their stability and propagation as well as to their ability to deliver the desired products. Economic viability of such living modified organisms (LMOs) along with their safe generally recognized as safe (GRAS) status are considerations that determine their industrial applications.

Biosafety considerations dictate the choice of safe selectable markers to play an important role in food-grade vector systems. Thus, the use of antibiotic resistance genes as markers are not an option and need to be strictly avoided [7]. Most of LAB secrete $\beta$-galactosidase and frequently generate revertants upon the use of an antibiotic resistance gene as a selectable marker. Due to this, there is difficulty in screening out the transformants on media containing X-gal and antibiotics and attempts to find more appropriate ways of screening transformants are continuing [8-10].

In the case of Gram-positive bacteria, the introduction of shuttle vector systems has greatly facilitated gene structure-function studies. However, the construction and range of application of such vectors available to date for Gram-positive bacteria are very inadequate in flexibility and variety. The major problems encountered include the inability to survive in new host strains, high molecular weight leading to low copy number, limited availability of restriction sites for the cloning of novel fragments, instability resulting from large size of fragment inserts, limited host interchangeability, etc. [11, 12]. Thus, recent research in this field has focused on designing of novel, versatile, and efficient shuttle vector systems for Gram-positive bacteria including lactic acid bacterial strains.

Pediococci are comprised of a diverse group of Grampositive homofermentative $\mathrm{LAB}$, found as saprophytes on vegetable material. These bacteria have been used in the fermentation of vegetables and meats at industrial level $[13,14]$. Pediococcus acidilactici MTCC 5101 is a GRAS LAB strain capable of secreting pediocin CP2. Biosafety assessment of this strain revealed it to have a nonhemolytic, catalase-negative, gelatinase-negative, and DNase-negative phenotype (unpublished data) and thus can serve as an attractive host for producing recombinant proteins in a biohazard free system. This strain harbors a $9.2 \mathrm{~kb}$ plasmid pCP289 which provides an opportunity to design a vector based on its molecular genetic properties. Nucleotide sequence analysis of pCP289 (accession no. KY886451) indicated the presence of a set of genes for pediocin production and transport, which is consistent with the sequence data of pediocin producing pediococcal strains previously reported in literature $[13,15,16]$. The operon consists of the gene pedA for the production of prepediocin, a precursor which matures to pediocin $\mathrm{CP} 2$ by the removal of a $\mathrm{N}$-terminal peptide, gene pedB encodes bacteriocin immunity protein, pedC gene product is known to facilitate transport along with PedD, which is the major protein involved in the translocation of pediocin as evident from its homology to various transport proteins. The leader peptide of PedA protein is processed by the respective $\mathrm{ABC}$ transporter Ped $\mathrm{D}$ protein whose proteolytic activity has been found to be associated with the first few amino acids in cytoplasmic domain. PedC protein consists of a short $\mathrm{N}$-terminal part located in the cytoplasm and a large domain downstream of the transmembrane sequence, located extracellularly. PedC and PedD proteins have been known to play common roles in the maturation and extracellular secretion of pediocins [1719]. The presence of secretory signal and transport proteins makes the plasmid an attractive resource for vector development with application for the production of therapeutics, food additives, or any immunogenic peptide $[16$, 20].

Many LAB species can be efficiently transformed by electroporation and have thus become amenable to generate recombinants [12]. Very few plasmids of genus Pediococcus have been studied in detail so far, and there is a limited availability of GRAS grade antibiotic resistance free, expression vectors for pediococcal strains [21-24]. Thus, it was proposed to develop a vector keeping in mind the biosafety aspect for industrial applications involving the use of Pediococcus and other LAB strains. The present work is aimed at the development of a refined expression system for genetic engineering of pediococci, equipped with biosafe recombinant selection markers and different replication origins to broaden the spectrum of transformable LAB species.

\section{Methods}

Bacterial strains, plasmids, and culture media

Bacterial strains and plasmids used in this work are listed in Table 1. P. acidilactici MTCC 5101 and $L$. brevis MTCC 1750 strains were routinely grown on MRS medium under microaerophilic conditions at $37^{\circ} \mathrm{C}$ without shaking. E. coli $\mathrm{DH} 5 \alpha$ and $\mathrm{K} 12$ were cultured using Luria-Bertani broth medium with vigorous shaking at $37^{\circ} \mathrm{C}$. For agar plates, $1.5-2.0 \%$ agar was added to the respective medium. The antibiotic concentrations used were $300 \mathrm{mg} / \mathrm{ml}$ erythromycin and $100 \mathrm{mg} / \mathrm{ml}$ ampicillin for $E$. coli and $5 \mathrm{mg} / \mathrm{ml}$ erythromycin for LAB. Growth media and antibiotics were purchased from HiMedia Laboratories. DNA polymerase, restriction, and 
Table 1 Bacterial strains and plasmids used in the study

\begin{tabular}{llll}
\hline Strain & Plasmid & Relevant characteristics & Origin or reference \\
\hline Pediococcus acidilactici MTCC5101 & pCP289 & Ped $^{+}$, isolated from chilly pickle & Kaur and Balgir [16] \\
Escherichia coli DH5a & pLES003 & Shuttle Vector, Amp ${ }^{R}$, Erm ${ }^{\mathrm{R}}$ & Wada et al. [24] \\
Escherichia coli K12 & pMK-RQ & dam $^{+}, \mathrm{dcm}^{+}$, tonA, rec ${ }^{-}$, Kan $^{\mathrm{R}}$ & GeneArt, Germany \\
Lactobacillus brevis MTCC1750 & - & Isolated during Sinki production & MTCC, Chandigarh \\
\hline
\end{tabular}

ligation enzymes were purchased from Bangalore Genei and New England Biolabs.

\section{DNA and PCR manipulation}

Nucleic acid manipulations and general cloning procedures were performed according to Sambrook et al. [25]. Plasmid DNA purification was carried out with a HighSpeed Plasmid Mini Kit (Geneaid, Taiwan). Plasmid pCP289 from $P$. acidilactici MTCC 5101 was sequenced via next-generation sequencing on Illumina MiSeq platform (Xcelris Labs Ltd., Ahmedabad, India). PCR amplification was as described by Yan et al. [26] and performed with Thermal Cycler (Techne, UK). Table 2 lists the details of PCR-amplified DNA fragments. Restriction digestion and ligation reactions were carried out as per manufacturer conditions. PCR and restriction products were detected by electrophoresis on $1.5 \%(\mathrm{w} / \mathrm{v})$ agarose gel containing ethidium bromide and photographed by Gel Doc system (Biorad, USA).

\section{Construction of recombinant plasmid and strains}

DNA fragments designed for vector construction are depicted in Fig. 1. Plasmid pCP289 was used as a template for PCR amplification of pediocin operon and replication origin (oriPA) fragment. Pediocin operon was digested with BamHI and SphI and ligated to oriLB fragment extracted from plasmid pLES003 after double digestion with SphI and AflII generating fragment I. oriPA and oriLB consists of RepB and RepA replication proteins and "ori" iteron regions. oriPA fragment was double digested with SacI and KpnI and then ligated to synthetic bsh fragment with SacI and AflII restriction sites resulting in fragment II. Gene fragments encoding BSH and GFP were artificially synthesized (GeneArt, Germany) as per codon choice of $P$. acidilactici and received as separate inserts in vector pMK-RQ. The nucleotide sequence for bsh gene of $L$. fermentum NCDO 394 was retrieved from NCBI vide accession no. JQ293998 and was optimized as per the codon usage of $P$. acidilactici followed by synthesis. Fragment II was constructed by ligation of $b s h$ gene sequence to another synthetic sequence (GeneArt, Germany) comprised of constitutive erythromycin (ery) gene promoter and $L$. lactis Usp45 signal peptide after restriction digestion with AflII and EcoRI enzymes. Fragment III comprised of coding gene sequence for GFP, which was synthesized from GeneArt as per codon choice of $P$. acidilactici and received as an insert in vector $\mathrm{pMK}-\mathrm{RQ}$. It was retrieved after double digestion with restriction enzymes KpnI and BamHI. Fragments I and II were ligated together after digestion with AflII, and fragment III was then incorporated to generate the shuttle vector pPBT-GFP. This plasmid was electroporated into the $P$. acidilactici MTCC 5101 and L. brevis MTCC 1750 using BTX600 Electro Cell Manipulator [27]. The resulting strains showing the $\mathrm{Ped}^{+}, \mathrm{BSH}^{+}$, and $\mathrm{GFP}^{+}$phenotype were screened on MRS agar plates.

Further, the nucleotide sequence of the constructed vector was subjected to restriction analysis using Sequence Manipulation Suite or SMS (http://www.bioin formatics.org/sms2/). The unique sites for restriction enzymes in pediocin operon and $g f p$ marker genes were analyzed to be used as insertion points for cloning heterologous genes.

\section{Determination of plasmid copy number and segregational stability}

Plasmid copy number refers to the number of copies of a plasmid present per chromosome in a bacterium. The plasmid copy number was determined by the Avogadro number method described (https://cels.uri.edu/gsc/cndna. $\mathrm{html}$ ). Plasmid segregational stability was determined as

Table 2 List of PCR primer pairs used for amplification

\begin{tabular}{|c|c|c|c|c|}
\hline Primer pair, forward/reverse & Primer sequence $\left(5^{\prime}-3^{\prime}\right)^{a}$ & Template DNA & Target gene & Amplicon length (bp) \\
\hline $\begin{array}{l}\text { pedF } \\
\text { pedR }\end{array}$ & $\begin{array}{l}\text { BamHI-GGATCCTATCTAACTAATACTTGACA } \\
\text { Sphl-GCATGCCGCGAGGATTTCAC }\end{array}$ & Plasmid pCP289 & pedA-D & 3541 \\
\hline $\begin{array}{l}\text { oriF } \\
\text { oriR }\end{array}$ & $\begin{array}{l}\text { Sacl-GAGCTCATGGTAGCCTCTG } \\
\text { Kpnl-GGTACCGCTTACATTAACTT }\end{array}$ & Plasmid pCP289 & repB,ori & 1557 \\
\hline $\begin{array}{l}\text { gfpF } \\
\text { gfpR }\end{array}$ & $\begin{array}{l}\text { Kpnl-GGTACCAGTGTGTTGATAGTGCAGTAT } \\
\text { BamHII-GGATCCTTATTAATATAATTCATCCATAC }\end{array}$ & Plasmid pMK-RQ & $g f p$ & 867 \\
\hline
\end{tabular}

${ }^{a}$ Restriction enzyme sites are underlined 


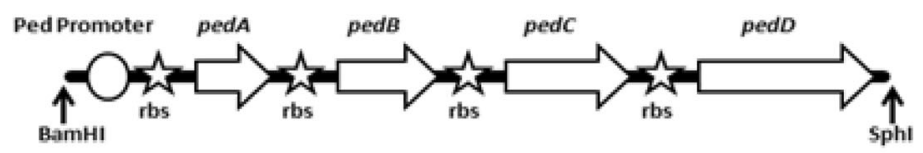

Ped operon
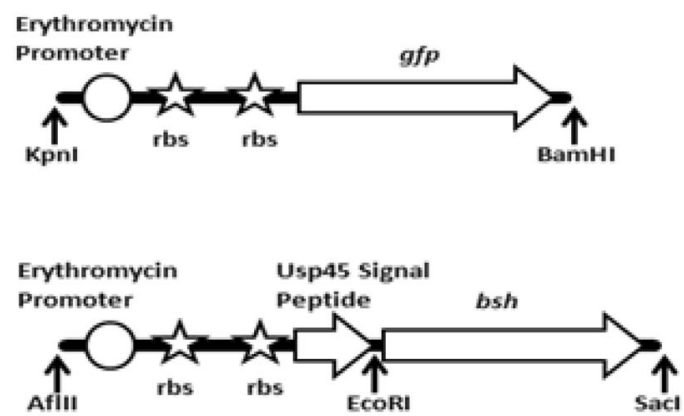

bsh

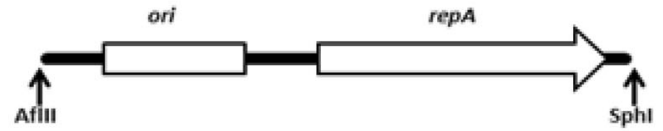

orilB

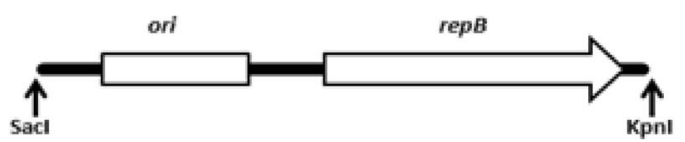

(L. brevis)

oriPA

(P. acidilactici)

Fig. 1 DNA fragments designed for vector construction

the fraction of culture that maintained the test plasmid after growth for 100 generations without any selective pressure [28, 29]. Cultures were assessed for plasmid maintenance at 0,50 , and 100 generations, respectively, by analyzing 100 randomly selected colonies for the plasmidborne phenotype.

\section{Assessment of selectable markers and heterologous genes \\ Bacteriocin activity assay for pediocin}

Well diffusion assay was performed to assess the bacteriocin activity in transformed strains [30, 31]. MRS hard agar $(1 \% \mathrm{w} / \mathrm{v})$ was overlaid with MRS soft agar $(0.75 \%$ $\mathrm{w} / \mathrm{v})$ seeded with approximately one million cells of indicator Enterococcus faecalis. Thirty microliters of heatinactivated culture supernatant of transformed $P$. acidilactici MTCC 5101 and L. brevis MTCC 1750 was added to wells on agar plates and incubated at $37^{\circ} \mathrm{C}$ for $24 \mathrm{~h}$. After overnight incubation, the antimicrobial activity was demonstrated by clear zone around the wells. The diameter of the inhibition zone was measured after the incubation of strains $(24-72 \mathrm{~h})$ in appropriate conditions.

\section{Green fluorescent protein}

The expression of GFP was detected by the spread plate method and epifluorescence microscopy [32]. Overnight grown cultures of transformed $P$. acidilactici MTCC 5101 and L. brevis MTCC 1750 were diluted and plated on MRSA plates and incubated at $37^{\circ} \mathrm{C}$ for $18-24 \mathrm{~h}$. The plates were then observed under UV light for fluorescence and photographed. For epifluorescence microscopy, dilution of overnight-grown bacterial suspensions was smeared on microscopic slides and production was examined with a fluorescent microscope equipped with a modular filter cube with excitation and emission filters for fluorescence detection and a photographic unit (Leica, Germany).

\section{Bile salt hydrolase (BSH) activity}

$\mathrm{BSH}$ activity was measured by the direct plate method described by Dashkevicz and Feighner [33] with a few modifications and ninhydrin biochemical assay [34]. For plate method, MRS agar plates containing $0.5 \%$ bile salt mixture were streaked with overnight grown cultures of P. acidilactici MTCC 5101 and L. brevis MTCC 1750 with incubation at $37{ }^{\circ} \mathrm{C}$ under anaerobic conditions for $48-72 \mathrm{~h}$. BSH activity was indicated by the presence of hydrolyzed products of the salts, viz. cholic acid or deoxycholic acid that precipitated in the agar medium in and around bacterial colonies [35, 36].

The ninhydrin biochemical method described previously by Liong and Shah [34] was used with a few modifications to determine specific $\mathrm{BSH}$ activity. It is based 
on determining the amount of amino acids released from conjugated bile salts [36, 37]. Since BSH in this study was secreted into the media, cell disruption steps were omitted and $0.1 \mathrm{ml}$ of cell-free supernatant was mixed with $0.8 \mathrm{ml} 0.1 \mathrm{M}$ sodium phosphate buffer $(\mathrm{pH}$ 6.0) and $0.1 \mathrm{ml}$ of $50 \mathrm{mM} / \mathrm{l}$ of respective conjugated bile salt (GC, TC, and TDC) and incubated at $37^{\circ} \mathrm{C}$ for 30 min. This was followed by an immediate addition of $0.75 \mathrm{ml}$ of $15 \%(\mathrm{w} / \mathrm{v})$ trichloroacetic acid to $0.75 \mathrm{ml}$ aliquots of mixture and centrifugation at $13,000 \mathrm{~g}$ at $4{ }^{\circ} \mathrm{C}$ for $10 \mathrm{~min}$. To $1 \mathrm{ml}$ of the supernatant, $2 \mathrm{ml}$ ninhydrin reagent $[0.5 \mathrm{ml} 1 \%$ ninhydrin in $0.5 \mathrm{M}$ citrate buffer $(\mathrm{pH}$ 5.5), $1.2 \mathrm{ml} \mathrm{30 \%} \mathrm{glycerol,} 0.2 \mathrm{ml} 0.5 \mathrm{M}$ citrate buffer $\mathrm{pH}$ 5.5) was added. The mixture was kept in a boiling water bath for $30 \mathrm{~min}$ and subsequently cooled in ice water. Lastly, the absorption was recorded at $570 \mathrm{~nm}$ and the amount of product formed was estimated from a calibration curve generated using glycine or taurine separately. One unit of BSH activity was defined as the amount of enzyme that liberated $1 \mu \mathrm{M}$ amino acid from the substrate per minute. The specific activity was defined as the number of units of activity per milligram of protein.
The Lowry method was used to measure the protein concentrations in the supernatant using bovine serum albumin (BSA) as standard [38]. All experiments in this study were performed in triplicate. BSH activity of each sample was measured against glycocholate (GC), taurocholate (TC), and taurodeoxycholate (TDC) substrates [36].

\section{Nucleotide sequence accession numbers}

The plasmid pCP289 nucleotide sequence was deposited in the GenBank database vide accession number KY886451. For the sequence of pPBT-GFP, see Additional file 1.

\section{Results}

Construction of expression vector PPBT-GFP

Schematic representation of construction protocol followed by a LAB shuttle vector pPBT-GFP is shown in Fig. 2. Template plasmids, pCP289 (P. acidilactici MTCC 5101), pLES003 (L. brevis MTCC 1750), and pMK-RQ (E. coli DH5 $\alpha$ ) were extracted from respective strains and analyzed by agarose gel electrophoresis

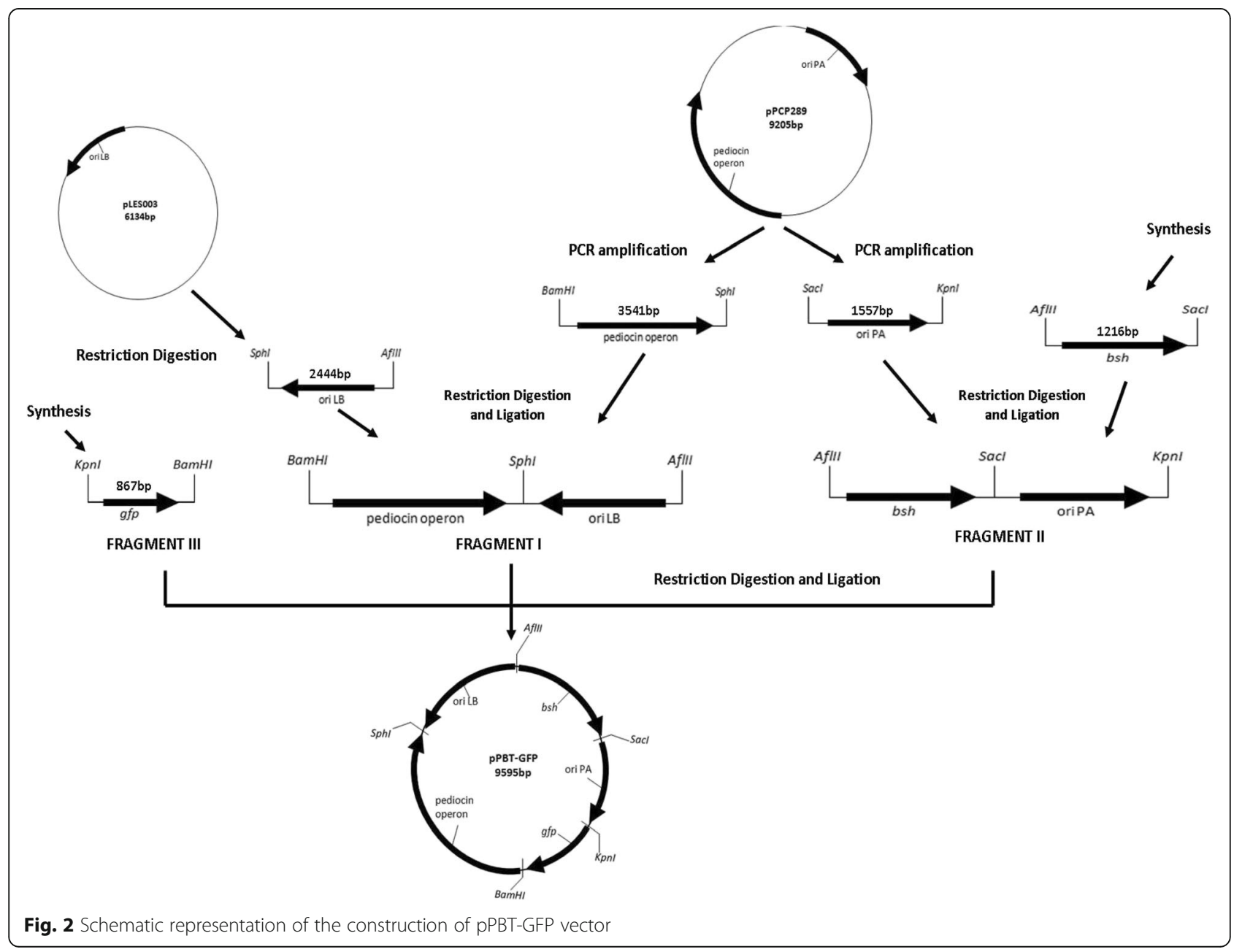


(Additional file 1: Figure S1). Similarly, PCR amplified and restriction digested fragments, namely pediocin operon, oriPA, oriLB, $b s h$, and $g f p$ were also analyzed on gel (Additional file 1: Figure S2). "Fragment I" was generated by ligation of $3.5 \mathrm{~kb}$ pediocin operon from pCP289 and $2.4 \mathrm{~kb}$ oriLB from pLES003. Similarly, 1.2 $\mathrm{kb}$ bsh was ligated to $1.5 \mathrm{~kb}$ oriPA resulting in "fragment II". Fragments I and II were ligated together followed by the incorporation of "fragment III" containing $0.8 \mathrm{~kb}$ coding sequence for $g f p$ gene. The size of the resulting vector is $9.6 \mathrm{~kb}$. It contains the dual replication origins from plasmids PCP289 and pLES003 and is able to replicate efficiently in P. acidilactici MTCC5101 and L. brevis MTCC1750 host strains. Genes for production and expression of pediocin and green fluorescent protein act as recombinant selection markers. The expression of heterologous bile salt hydrolase gene from L. fermentum NCDO394 was successfully achieved in $P$. acidilactici MTCC 5101 and L.brevis MTCC 1750.

For further cloning heterologous inserts in vector pPBT-GFP, insertion sites located within the selectable marker genes are an effective means to select transformants. Insertion will lead to the disruption of marker gene function and related phenotype in transformed cells, which can be used to screen out the recombinant cells. Therefore, restriction analysis of pPBT-GFP vector was carried out using SMS which indicated the presence of unique enzyme sites within pediocin gene cluster. The insertion sites in any of the pediocin producing genes pedA or pedD that is essential for translocation of pediocin can be efficiently used to suppress $\mathrm{Ped}^{+}$phenotype. NheI and BmtI sites within gene pedA and XbaI site in pedD can be used for insertional cloning. A unique site for BstXI is present in $g f p$ gene for insertional activation of this selectable marker. Moreover, all the DNA fragment inserts in the shuttle vector pPBTGFP have been cloned using cohesive-end restriction enzyme sites and can be easily replaced with desirable heterologous inserts with similar enzyme sites (Fig. 3).

\section{Plasmid copy number and segregational stability}

Shuttle vector pPBT-GFP showed a PCN value of $\sim 4$ copies per cell in P. acidilactici MTCC 5101 and $\sim 3$ copies per cell in L. brevis MTCC 1750. Although transformation efficiency was found to be comparable to the reported studies involving electro-transfomation in $\mathrm{LAB}$ strains [36, 39], plasmid PPBT-GFP has a low copy number and displayed a segregational stability of up to 50 generations in both the host cells (Table 3).

\section{Bacteriocin activity}

To check for pediocin CP2 production in transformed $P$. acidilactici MTCC 5101 and L. brevis MTCC 1750, standard agar well diffusion assay was carried out using

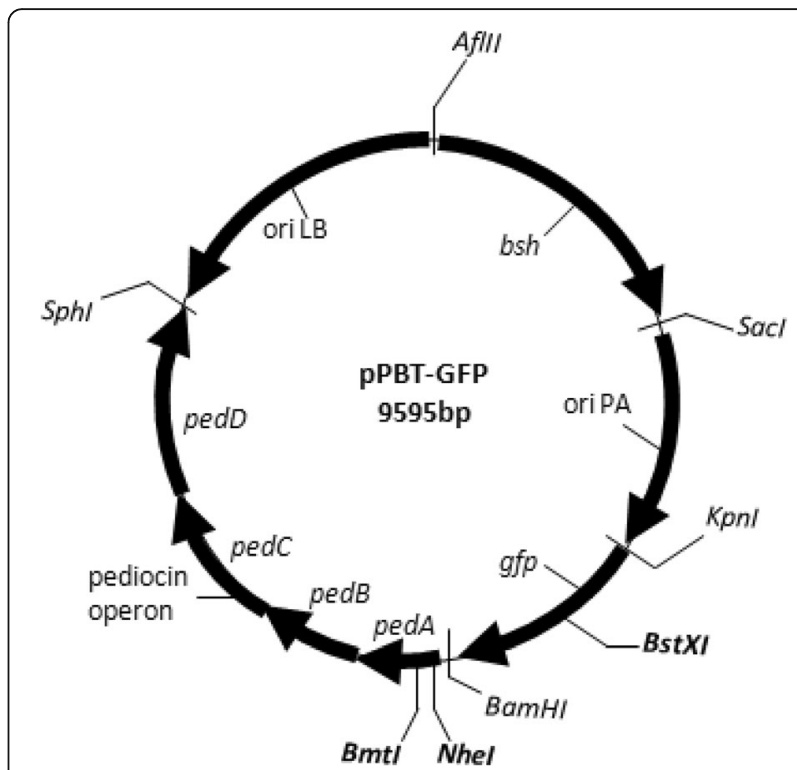

Fig. 3 Schematic model of shuttle vector PPBT-GFP showing potential insertion sites for cloning of heterologous inserts. Unique restriction enzyme sites for insertion by suppression of selectable markers are in bold case

E. faecalis as the indicator strain. Non-transformed $P$. acidilactici MTCC 5101 was used as a control. A definite zone of inhibition was observed in the plates after 24 h. Figure 4 shows the zone of inhibition against the indicator strain and Table 4 lists the diameter of the zone. The transformed and control bacterial strains showed similar inhibition zones depicting efficient expression, production, and secretion of genes of pediocin operon.

\section{Expression of green fluorescent protein}

The transformation of LAB strains in this study with plasmid expressing $g f p$ gene under constitutive promoter for erythromycin gene resulted in visible fluorescence in colonies under UV light. Figures 5 and 6 show the bacterial colonies under UV light and bacterial cells under a fluorescence microscope equipped with excitation and emission filters for GFP. Notably, the strains fluoresced only transiently, and no toxicity of GFP for the bacterial hosts and no protein degradation in cell extracts or structural instability of the plasmid were observed.

Table 3 Transformation efficiency, copy number, and segregational stability of pPBT-GFP

\begin{tabular}{llll}
\hline Strain & $\begin{array}{l}\text { Transformation } \\
\text { efficiency } \\
\text { (cfu/ug plasmid DNA) }\end{array}$ & $\begin{array}{l}\text { Copy } \\
\text { number }\end{array}$ & $\begin{array}{l}\text { Segregational stability } \\
\text { (No. of generations) }\end{array}$ \\
\hline $\begin{array}{l}\text { P. acidilactici } \\
\text { MTCC 5101 }\end{array}$ & $2.9 \pm 0.1 \times 10^{4}$ & 4.4 & 50 \\
$\begin{array}{l}\text { L. brevis } \\
\text { MTCC 1750 }\end{array}$ & $1.6 \pm 0.1 \times 10^{5}$ & 2.8 & 50 \\
\hline
\end{tabular}



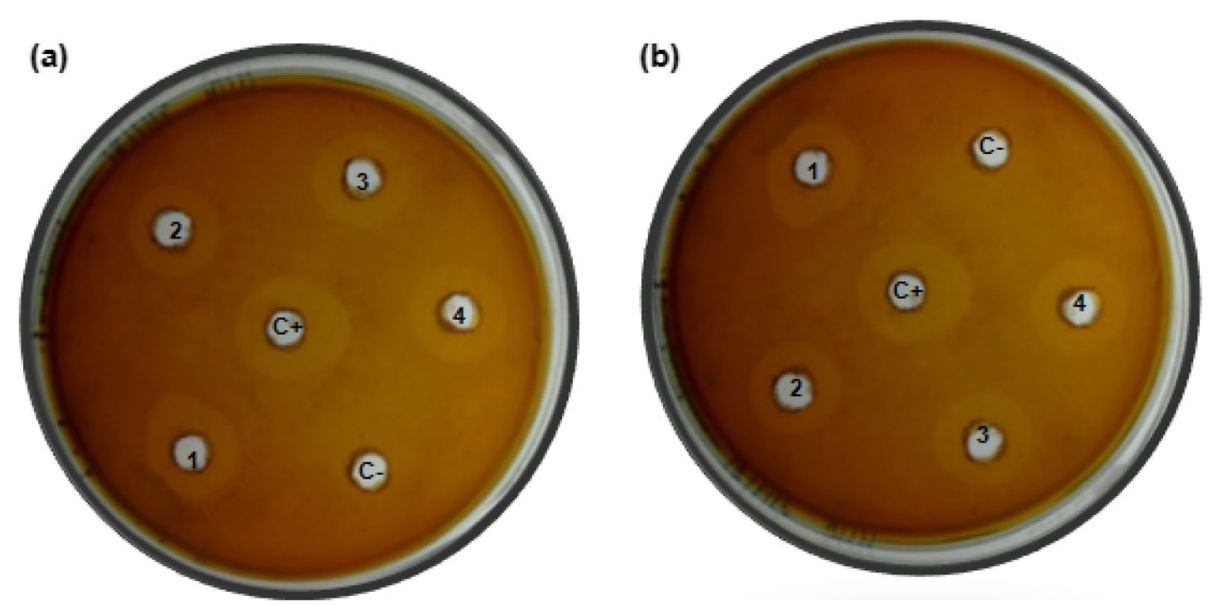

Fig. 4 Bacteriocin agar well diffusion assay showing the zone of inhibition against the indicator E. faecalis. a 1-4: P. acidilactici MTCC 5101 transformed with pPBT-GFP. b 1-4: L. brevis MTCC 1750 transformed with pPBT-GFP. C+ control native P. acidilactici MTCC 5101, C- plasmid cured P. acidilactici MTCC 5101

\section{Bile salt hydrolase activity}

In direct plate assay for $\mathrm{BSH}$, the growth of transformed LAB strains on MRSA plates with $0.5 \%$ bile salt mixture resulted in white precipitates around active bacterial colonies due to precipitation of free bile acids (Fig. 7). The plasmid cured host strains served as a negative control marked with absence of inhibition zone and original isolate; P. acidilactici MTCC 5101 harboring native pCP289 plasmid with pediocin operon was used as a positive control. The results indicated fewer $\mathrm{Bsh}^{+}$colonies in plates with L. brevis MTCC 1750 as compared to $P$. acidilactici MTCC 5101, possibly due to strainspecific expression of BSH.

BSH activities of the LAB strains transformed with pPBT-GFP were measured towards sodium glycocholate (GC), sodium taurocholate (TC), sodium taurodeoxycholate (TDC), and bile salt mixture using quantitative ninhydrin assay (Table 5). Values were found to be identical with a specific activity of BSH from $L$. fermentum NCDO 394 previously reported by Kumar et al. [36] against the listed bile salts. Since BSH enzymes extracted from different sources tend to have different substrate specificities [34, 37, 40], both the strains showed a high specific enzyme activity towards glycine-conjugated bile salts as compared to tauro-conjugated salts. $P$.

Table 4 Zone of inhibition of pediocin against E. faecium

\begin{tabular}{ll}
\hline Strain & $\begin{array}{c}\text { Zone of inhibition } \\
\text { Diameter }^{\mathrm{a}}(\mathrm{mm})\end{array}$ \\
\hline Plasmid cured hosts (negative control) & 0 \\
P. acidilactici MTCC 5101 (positive control) & $18 \pm 0.5$ \\
P. acidilactici MTCC 5101 with pPBT-GFP & $17 \pm 0.7$ \\
L. brevis MTCC 1750 with pPBT-GFP & $21 \pm 0.5$
\end{tabular}

${ }^{a}$ Values are mean of triplicate \pm standard error of means acidilactici MTCC 5101 showed a higher BSH-specific activity towards all the three bile salts as compared to $L$. brevis MTCC 1750 as evident from ninhydrin assay.

\section{Discussion}

Keeping biosafety aspect in view, a shuttle expression vector was developed for $P$. acidilactici MTCC 5101 and L. brevis MTCC 1750. Both LAB strains have been isolated from human food sources and can be safely used at commercial scale. The designed system included pediocin operon and green fluorescent protein as selectable markers, replication origins for two LAB strains based on theta-replication, and heterologous bile salt hydrolase gene. Vector derivation was accomplished by recombining desired fragments to construct vector pPBT-GFP, followed by electroporation into plasmid cured $\mathrm{LAB}$ strains. Transformants with $\mathrm{Ped}^{+}, \mathrm{GFP}^{+}$, and $\mathrm{BSH}^{+}$ phenotype containing vector pPBT-GFP were screened on MRSA plates.

LAB plasmids are extremely diverse in terms of size (from $0.87 \mathrm{~kb}$ to more than $250 \mathrm{~kb}$ ), copy number (from 1 to more than 100 plasmids per cell), and phenotypes (sugar fermentation, bacteriocin production, etc.) conferred on their hosts [12]. Large-sized plasmid usually have lower copy numbers, and in order to ensure proper distribution of plasmid copies to both daughter cells, a partition system has been evolved in the case of low copy plasmids [41]. Control of the plasmid copy number is achieved by modulating the intracellular concentration of the initiator protein with negative regulatory circuits that may include antisense RNA, both antisense RNA and proteins, and sites for binding initiator protein [42]. Plasmids with theta-type replicons tend to have a narrower host range than the rolling circle counterparts. However, a narrow host range is advantageous in 

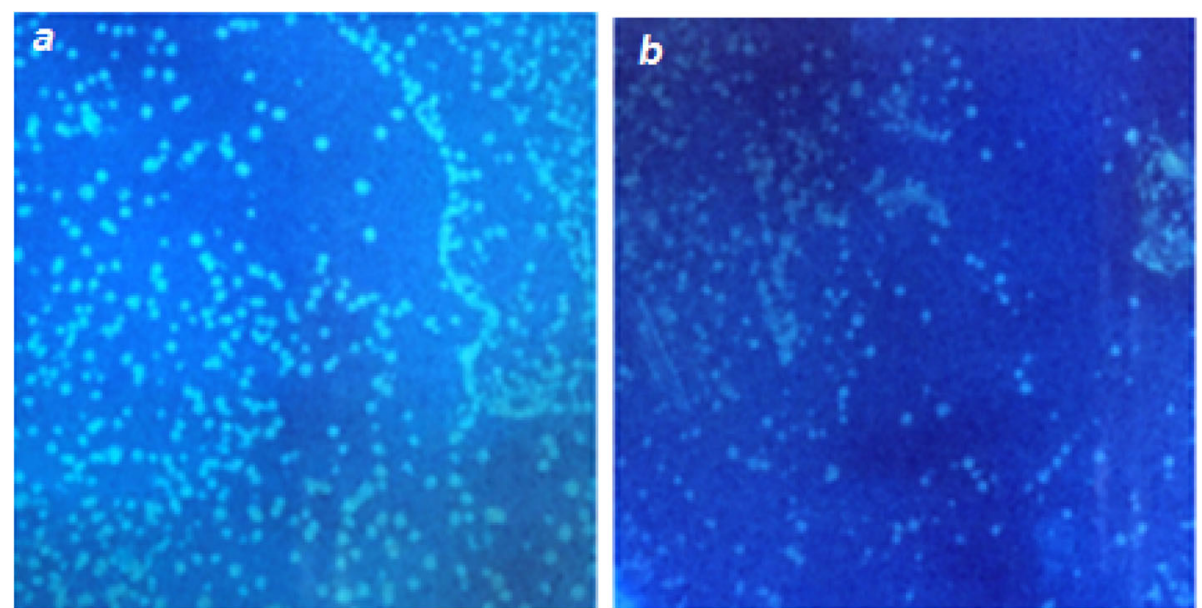

Fig. 5 Detection of fluorescence in bacterial colonies on MRSA plates under UV light. a P. acidilactici MTCC 5101. b L. brevis MTCC 1750
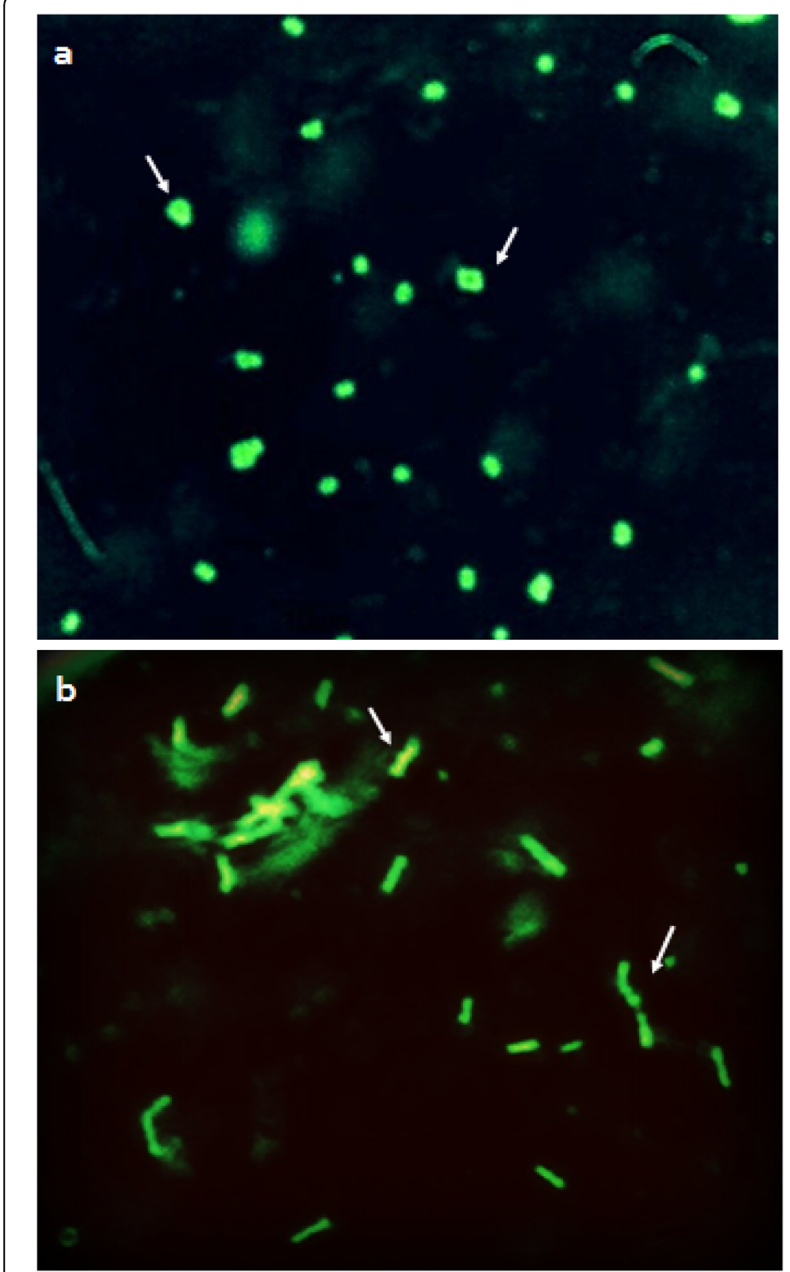

Fig. 6 Cells of host LAB strains under fluorescence microscope $(x$ 3000). a P. acidilactici MTCC 5101. b L. brevis MTCC 1750. White arrows depict tetrads clusters of $P$. acidilactici and rods of $L$. brevis minimizing the chances of horizontal transfer of plasmids among bacteria, thus, making them safer in terms of containment. These safety aspects of plasmid based vectors are very significant while handling $L A B$ strains of commercial value [39]. In addition to the safety aspects of theta-replicating plasmids, these are also more stable both structurally and segregationally and can be used for cloning long DNA inserts [29, 42]. Shuttle vector pPBT-GFP was designed based on two theta-type replicons and was able to maintain itself for a fair number of generations $(\sim 50)$ in both the hosts. The copy number of pPBT-GFP in P. acidilactici MTCC 5101 and L. brevis MTCC 1750 was found to be 4.4 and 2.8, respectively, which revealed that PPBT-GFP has a low copy number and is stable in host cells. Therefore, the theta-type replication shuttle vector, pPBT-GFP, with its characteristics of narrow host range and stability in host cells may serve as an ideal tool for improving $L A B$ strains of commercial value using genetic engineering.

Most laboratories incorporate antibiotic-resistant genes in vectors for ease of screening and selecting for transformants and maintain the genetic modification of interest. However, strains to be applied in the food industry cannot potentially carry transferable antibiotic resistance markers. To address this issue, the design and development of markers other than antibiotic resistance genes are a requisite for promoting industrial use of these bacteria. Selectable markers based on specific heterologous genes from other LAB, like resistance to heavy metals, production of antimicrobial bacteriocinlike substances, and utilization of certain complex carbohydrates, have been developed [43-49]. Table 6 lists the plasmid vectors used for cloning in P. acidilactici and $L$. brevis strains. Most of these plasmids encode antibiotic resistance genes as selectable marker which is a major safety concern for food-based applications. Therefore, in 


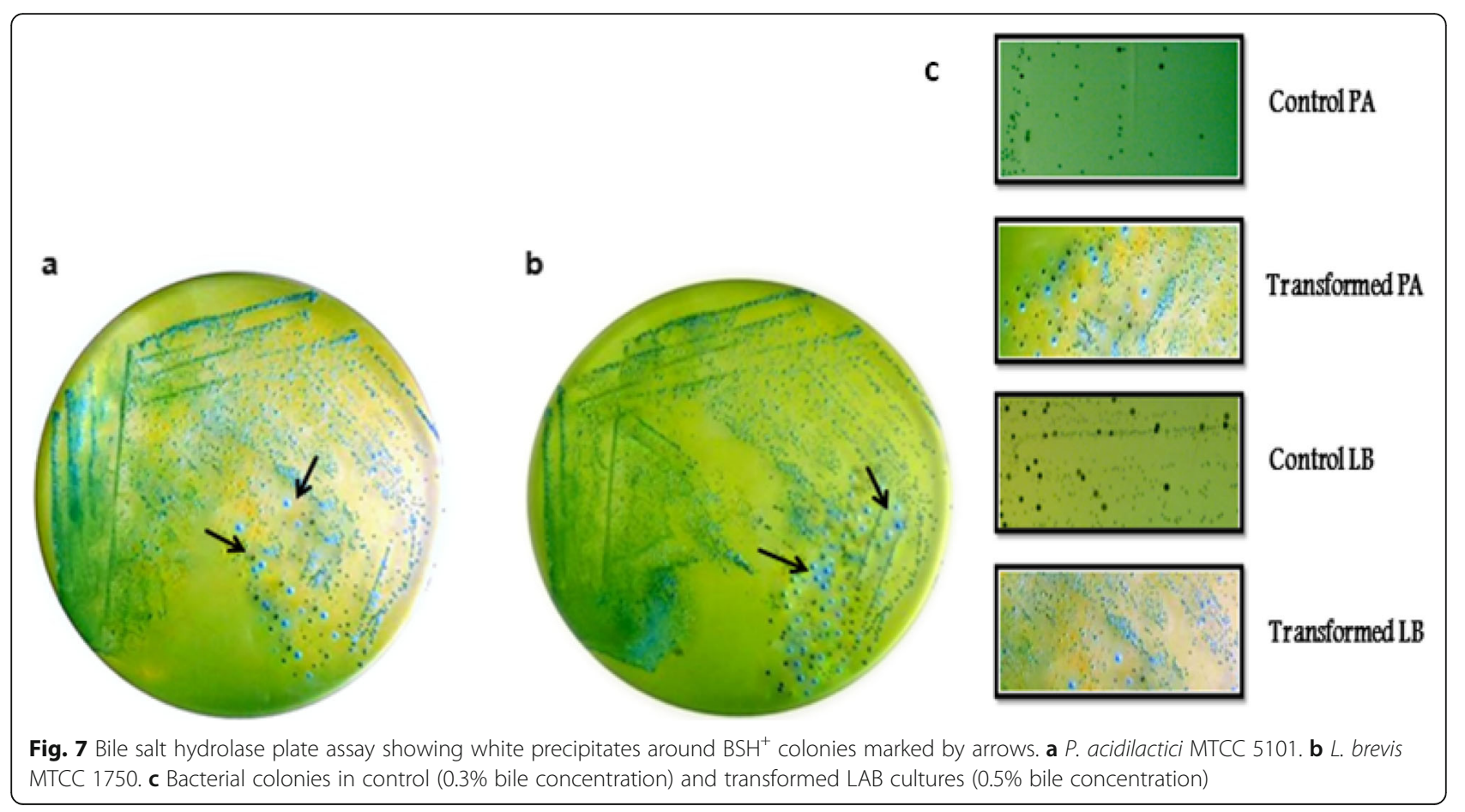

the present study, a shuttle vector pPBT-GFP was constructed without any antibiotic resistance marker genes. In contrast, genes encoding pediocin production and secretion have been incorporated, which has an effective wide-ranging antimicrobial activity, making it a promising and reliable system for industrial applications.

Apart from pediocin, green fluorescent protein (GFP) is a commonly employed selectable marker with potential ease of visualization as an advantageous trait when compared with other reporter proteins. The safety of GFP protein has been evaluated in in vivo studies in mice [50] and has also been used to tag LAB strains [32]. Although a majority of studies have reported a very strong fluorescence in the case of $E$. coli strains transformed with the $g f p$-carrying plasmids under the control of constitutive promoters, very few positive reports are available in the case of different LAB strains [51]. GFP was expressed in LAB strains P. acidilactici and L. brevis, using the vector pPBT-GFP under the control of a constitutive erythromycin (ery) gene promoter derived from vector pH 2515 [52]. A strong and consistent fluorescence due to GFP can only be observed in colonies synthesizing massive quantities of protein. On the other hand, a low-level expression can be studied using epifluorescence microscopy and western blotting. This phenotype thus seemed essentially correlated with the amount of GFP produced. A strong fluorescence was observed for both LAB strains transformed with pPBTGFP. The promoter sequence does not encode any antibiotic resistance protein and was used for a stable and strong expression of $g f p$ gene placed next to it. Notably, a transient fluorescence was observed with no toxicity of GFP observed to the bacterial hosts and no reduction in colony numbers as compared to non-transformed bacterial cells.

Probiotic LAB strains have been reported to possess hypocholesterolemic properties mainly attributable to the production of the enzyme and bile salt hydrolase (BSH). Most of the probiotic LAB strains show bile tolerance or resistance to varied levels and BSH enzymes have been purified and characterized from a number of LAB species [36, 53, 54]. These enzymes belong to

Table 5 Specific bile salt hydrolase (BSH) activity of LAB strains

\begin{tabular}{|c|c|c|c|c|}
\hline \multirow{3}{*}{$\begin{array}{l}\text { LAB strains transformed } \\
\text { with pPBT-GFP }\end{array}$} & \multicolumn{4}{|l|}{ BSH $_{\text {activity }}{ }^{\mathrm{a}}$} \\
\hline & Sodium glycocholate (GC) & Sodium taurocholate (TC) & Sodium taurodeoxycholate (TDC) & Bile salt mixture \\
\hline & Specific activity (U/mg) & Specific activity (U/mg) & Specific activity (U/mg) & Specific activity (U/mg) \\
\hline P. acidilactici MTCC 5101 & $126.1 \pm 10.6$ & $68.1 \pm 7.6$ & $90.2 \pm 8.7$ & $128.3 \pm 9.7$ \\
\hline L. brevis MTCC 1750 & $95.4 \pm 4.2$ & $43.4 \pm 5.3$ & $35.5 \pm 9.8$ & $88.1 \pm 6.3$ \\
\hline
\end{tabular}

${ }^{\mathrm{a}}$ Values are means of triplicates \pm standard error of means 
Table 6 Vectors used for cloning in strains of $P$. acidilactici and L. brevis

\begin{tabular}{|c|c|c|c|c|}
\hline Plasmid & Host strain(s) & Size (kb) & $\begin{array}{l}\text { Relevant } \\
\text { characteristics }\end{array}$ & Reference \\
\hline $\begin{array}{l}\text { pRS4 } \\
\text { derivatives } \\
\text { (pRS4C1- } \\
\text { C3) }\end{array}$ & $\begin{array}{l}\text { P. pentosaceus } \\
\text { P. acidilactici } \\
\text { L. plantarum } \\
\text { L. casei } \\
\text { E. coli }\end{array}$ & 7.8 & $A m p^{R}, C^{R}$ & [21] \\
\hline pAMJAB & $\begin{array}{l}\text { L. lactis MG1363 } \\
\text { P. acidilactici, E. } \\
\text { coli }\end{array}$ & 9.0 & $\begin{array}{l}\mathrm{Em}^{\mathrm{R}} \\
\text { Pediocin PA-1 } \\
\text { pedA } \\
\text { Immunity gene } \\
\text { pedB }\end{array}$ & [22] \\
\hline pRS5 & $\begin{array}{l}\text { P. pentosaceus } \\
\text { E. coli }\end{array}$ & 10.1 & $A m p^{R}, C m^{R}$ & [23] \\
\hline pLES003 & $\begin{array}{l}\text { L. brevis } \\
\text { E. coli }\end{array}$ & 6.1 & $A m p^{R}, E m^{R}$ & [24] \\
\hline pCP289 & $\begin{array}{l}\text { P. acidilactici } \\
\text { MTCC } 5101\end{array}$ & 9.2 & $\begin{array}{l}\text { Ped operon } \\
\text { RepB ori }\end{array}$ & $\begin{array}{l}\text { Present } \\
\text { study }\end{array}$ \\
\hline pPBT-GFP & $\begin{array}{l}\text { P. acidilactici } \\
\text { MTCC } 5101 \\
\text { L. brevis MTCC } \\
1750\end{array}$ & 9.6 & $\begin{array}{l}\text { Ped operon, RepA, } \\
\text { ori LB, RepB } \\
\text { ori PA, } \\
\text { GFP, BSH }\end{array}$ & $\begin{array}{l}\text { Present } \\
\text { study }\end{array}$ \\
\hline
\end{tabular}

choloylglycine hydrolase family of enzymes and have been classified as N-terminal nucleophilic (Ntn) hydrolases with an $\mathrm{N}$-terminal cysteine residue, which serves as the nucleophile and proton donor in the catalytic process [55]. An autoproteolytic reaction leads to the removal of initiation formyl methionine, thus making Cys-1 residue the catalytic center in Ntn hydrolase superfamily [56] and removal or replacement of $\mathrm{N}$ terminal Cys with other potential nucleophilic residues, Ser or Thr, generated an inactive enzyme [57-59]. The present study describes cloning and heterologous expression of intracellular BSH enzyme produced in $L$. fermentum NCDO 394 using shuttle vector pPBT-GFP. $P$. acidilactici and $L$. brevis are also acid- and biletolerant strains and may contain gene(s) for bile salt hydrolase as well $[16,33,53,60]$. However, limited data is available as to the characterization of $\mathrm{BSH}$ in these strains; incorporation of heterologous bsh gene via cloning may also be considered as an enhancement strategy by introduction of an extra copy of bsh gene in addition to the existing one. Recombinant BSH was successfully produced and secreted using L. lactis Usp45 signal peptide under constitutive ery gene promoter, the same as the one used for GFP expression. Usp45 signal peptide is commonly used for heterologous protein secretion in $L$. lactis. The sec pathway is a ubiquitous secretion system which is based on the translocation of protein across the membrane, followed by cleavage of $\mathrm{N}$-terminal signal peptide by a signal peptidase, thus releasing the protein into the medium [61]. The nucleotide sequence analysis of gene encoding Usp45 protein indicated the presence of a $1383 \mathrm{bp}$ open reading frame encoding 461 amino acid long protein with a 27 amino acid signal peptide at $\mathrm{N}$-terminal [62] which undergoes cleavage, releasing the mature protein extracellularly [63]. van Asseldonk et al. [64] reported a very high secretion efficiency for Usp45 signal peptide and has been used for the secretion of heterologous proteins in a number of Gram-positive LAB host strains since then $[65,66]$. The successful secretion of $\mathrm{BSH}$ in the present work indicated that the Usp45 signal peptide is functional in Pediococcus and Lactobacillus species as well.

Since the presence of bile imposes stress towards the growth and survival in majority of LAB species, this mechanism can also be used as a selective pressure for plasmid maintenance in the host LAB strains $[67,68]$. In the present study, $P$. acidilactici MTCC 5101 was observed to be sensitive to bile salts at $0.3 \%$ concentration in the medium; however, on transformation, the strain was found to maintain its growth even at $0.5 \%$. Thus, $0.5 \%$ concentration can be used as a selective pressure for selection and maintenance of the vector in the transformants. This also obviates the need for use of any other selective pressure for the maintenance of the plasmid vector. Specific BSH activity revealed that substrate preference of $\mathrm{BSH}$ enzyme is more inclined towards glycine-conjugated bile substrates as compared to taurine-conjugated salts, consistent with the data already reported in literature for other LAB BSH enzymes [36, 37, 54, 59, 69-71]. BSH from L. fermentum NCDO 394 has already been well characterized by Kumar et al. [36] and found to be stable and functional in a range of $\mathrm{pH}$ and temperature values identical to the human body.

Hence, LAB hosts carrying shuttle vector pPBT-GFP with a stable copy number and narrow host range can be efficiently used as cholesterol-lowering probiotic strains for use in functional foods at an industrial scale too. Such genetic tools also can be employed for the production of various heterologous proteins in foodbased systems for imparting traits with beneficial effects for humans. Since pediococci are usually associated with vegetables and meat products and are observed to grow poorly in dairy or milk products, the present study selected a dairy-based system in $L$. brevis to be used as shuttle host for applications involving dairy products.

The present study was designed for developing expression systems for pediococcal strains due to limited availability of vectors for genetic manipulation in species of the genus Pediococcus (Table 6). Studies have reported probiotic characteristics of various pediococcal strains isolated from varied habitats [20,60, 72-74], which further emphasizes on the need for improvement in members of this genus. Strains of L. brevis also display a limited availability of cloning and expression systems for the production of recombinant products. Hence, the 
shuttle vector pPBT-GFP was designed to widen the industrial potential of such strains by genetic improvement. Such efficient and stable expression vectors are a must nowadays, and research must be geared towards the development of efficient vectors for LAB strains to be used in food based applications.

\section{Conclusion}

This research work reports the development of a LAB/ LAB shuttle vector pPBT-GFP efficiently replicating in LAB species, Pediococcus acidilactici MTCC 5101 and Lactobacillus brevis MTCC 1750. Genes for the production and expression of pediocin and green fluorescent protein were used as selection markers. Heterologous gene-encoding bile salt hydrolase with cholesterollowering potential was successfully cloned and secreted using Usp45 signal peptide mediated secretory pathway.

\section{Supplementary information}

Supplementary information accompanies this paper at https://doi.org/10. 1186/s43141-019-0013-4

Additional file 1: Figure S1. Agarose gel electrophoresis of various plasmids used in the study, (a) Lane 1: NEB Supercoiled DNA ladder; Lane 2: Shuttle vector PPBT-GFP; Lane 3: Plasmid pLES003; Lane 4: Plasmid pCP289; Lane 5: Vector PMK-RQ. Multiple bands are visible due to supercoiled, partially nicked and linear forms of plasmids. Figure S2. Agarose gel electrophoresis of DNA fragments used for vector development, Lane 1: Novagen Perfect DNA ladder; Lane 2: Pediocin operon; Lane 3: oriLB; Lane 4: oriPA; Lane 5: bsh; Lane 6: gfp. Sequence of Shuttle Vector PPBTGFP, $9.6 \mathrm{~kb}$.

\section{Abbreviations}

BSA: Bovine serum albumin; BSH: Bile salt hydrolase; GFP: Green fluorescent protein; GRAS: Generally recognized as safe; LAB: Lactic acid bacteria; MTCC: Microbial Type Culture Collection; NCBI: National Centre for Biotechnology Information; UV: Ultraviolet; w/V: Weight/volume

\section{Acknowledgements}

The authors would like to acknowledge DST and ICMR, New Delhi, for the financial assistance to PPB and TK. The authors are grateful to BK for providing plasmid pLESO03.

\section{Authors' contributions}

PPB and BK designed and supervised the study and contributed to the manuscript. TK conducted the practical work and prepared the manuscript. All authors have thoroughly read the final manuscript and approved it.

\section{Funding}

This work was supported by the Department of Science and Technology, Government of India vide Major Research Project no. SR/SO/HS-38/2009.The authors would like to acknowledge ICMR, New Delhi, for providing financial assistance to TK (Senior Research Fellowship vide no. 3/1/1\&2/36/2014-Nut. dated 24/05/2016). The funders had no role in the study design, data collection and analysis, decision to publish, and preparation of manuscript.

\section{Availability of data and materials}

All data generated or analyzed during this study are included in this published article and its supplementary information files.

\section{Ethics approval and consent to participate}

Not applicable
Consent for publication

Not applicable

\section{Competing interests}

The authors declare that they have no competing interests.

Received: 25 August 2019 Accepted: 2 October 2019

Published online: 18 November 2019

\section{References}

1. Makarova K, Slesarev A, Wolf Y, Sorokin A, Koonin E, Pavlov A et al (2006) Comparative genomics of the lactic acid bacteria. Proc Natl Acad Sci U S A 103:15611-15616

2. Liu W, Sun Z, Zhang J, Gao W, Wang W, Wu L et al (2009) Analysis of microbial composition in acid whey for dairy fan making in Yunnan by conventional method and 16S rRNA sequencing. Curr Microbiol 59:199-205. https://doi.org/10.1007/s00284-009-9423-X

3. Liu W, Bao Q, Qing M, Chen X, Sun T, Li M et al (2012) Isolation and identification of lactic acid bacteria from Tarag in eastern inner Mongolia of China by 165 rRNA sequences and DGGE analysis. Microbiol Res 167:110115. https://doi.org/10.1016/j.micres.2011.05.001

4. Wang D, Liu W, Ren Y, De L, Zhang D, Yang Y (2016) Isolation and identification of lactic acid bacteria from traditional dairy products in Baotou and Bayannur of Midwestern Inner Mongolia and q-PCR analysis of predominant species. Korean J Food Sci Animal Res 36(4):499-507

5. Miller N, Wetterstrom W (2000) The beginnings of agriculture: the ancient near East and North Africa. In: Kiple K, Ornelas K (eds) (eds)The Cambridge world history of food, 2nd edn. Cambridge University Press, Cambridge, pp $1123-1139$

6. van der Vossen JM, van der Lelie D, Venema G (1987) Isolation and characterization of Streptococcus cremoris Wg2-specific promoters. ApplEnvironMicrobiol 53:2452-2457

7. Takala T (2005) Nisin immunity and food-grade transformation in lactic acid bacteria, Academic Dissertation. University of Helsinki, Finland

8. Martin MC, Alonso JC, Suarez JE, Alvarez MA (2000) Generation of foodgrade recombinant lactic acid bacterium strains by site-specific recombination. Appl Environ Microbiol 66(6):2599-2604. https://doi.org/10. 1128/AEM.66.6.2599-2604.2000

9. Bron PA, Benchimol MG, Lambert J, Palumbo E, Deghorain M, Delcour J et al (2002) Use of the alr gene as a food-grade selection marker in lactic acid bacteria. Appl Environ Microbiol 68(11):5663-5670. https://doi.org/10. 1128/AEM.68.11.5663-5670.2002

10. Peterbauer $C$, Maischberger T, Haltrich D (2011) Food-grade gene expression in lactic acid bacteria. Biotechnol J 6(9):1147-1161. https://doi. org/10.1002/biot.201100034

11. Charpentier E, Anton Al, Barry P, Alfonso B, Fang Y, Novick RP (2004) Novel cassette-based shuttle vector system for Gram-positive bacteria. Appl Environ Microbiol 70(10):6076-6085

12. Cui Y, Hu T, Xiaojun Q, Zhang L, Ding Z, Dong A (2015) Plasmids from food lactic acid bacteria: diversity, similarity, and new developments. J Mol Sci 16 13172-13202

13. Marugg JD, Gonzalez CF, Kunka BS, Ledeboer AM, Pucci MJ, Toonen MY et al (1992) Cloning, expression, and nucleotide sequence of genes involved in production of pediocin PA-1, and bacteriocin from Pediococcus acidilactici PAC1.0. Appl Environ Microbiol 58(8):2360-2367

14. Kumar B, Balgir PP, Kaur B, Mittu B, Chauhan A (2012) In vitro cytotoxicity of native and rec-pediocin CP2 against cancer cell lines: a comparative study. Pharmaceut Anal Acta 3(8):183

15. Bukhtiyarova M, Yang R, Ray B (1994) Analysis of the pediocin AcH gene cluster from plasmid pSMB74 and its expression in a pediocin-negative Pediococcusacidilactici strain. Appl Environ Microbiol 60:3405-3408

16. Kaur B, Balgir PP (2006) Pediocin CP2 Gene localisation to plasmid pCP289 of Pediococcus acidilactici MTCC 5101. Internet J Microbiol 3(2):1-7

17. Ray B, Motlagh AM, Johnson MC, Bozoglu F (1992) Mapping of pSMB74, a plasmid encoding bacteriocin AcH production (Pap+) trait in Pediococcus acidilactici H. Lett Appl Microbiol 15:35-37

18. Venema K, Kok J, Marugg JD, Toonen MJ, Ledeboer AM, Venema G, Chikindas ML (1995) Functional analysis of the pediocin operon of Pediococcus acidilactici PAC1.0: PedB is the immunity protein and PedD is the precursor processing enzyme. Mol Microbiol 17:515-522 
19. Chikindas M, Emond E, Haandrikman AJ, Kok J, Leenhouts K, Pandian S et al (2010) Heterologous processing and export of the bacteriocins pediocin PA1 and lactococcin a in Lactococcus lactis: a study with leader exchange. Probiotics Antimicro Prot 2:66. https://doi.org/10.1007/s12602-009-9023-x

20. Balgir PP, Kaur B, Kaur T, Daroch N, Kaur G (2013) In vitro and in vivo survival and colonic adhesion of Pediococcus acidilactici MTCC5101 in human gut. Biomed Res Int 2013:1-9

21. Alegre MT, Rodriguez MC, Mesas JM (2005) Nucleotide sequence, structural organization and host range of pRS4, a small cryptic Pediococcus pentosaceus plasmid that contains two cassettes commonly found in other lactic acid bacteria. FEMS Microbiol Lett 250:151-156

22. Srikanth A, Halami PM (2008) Cloning of pediocin PA-1 and its immunity genes from Pediococcusacidilactici K7 using pAMJ shuttle vector into Lactococcuslactis MG1363. Indian J Biotechnol 7:550-553

23. Alegre MT, Rodriguez MC, Mesas JM (2009) Characterization of pRS5: a theta-type plasmid found in a strain of Pediococcus pentosaceus isolated from wine that can be used to generate cloning vectors for lactic acid bacteria. Plasmid 61:130-134

24. Wada T, Noda M, Kashiwabara F, Jeon HJ, Shirakawa A, Yabu H et al (2009) Characterization of four plasmids harboured in a Lactobacillus brevis strain encoding a novel bacteriocin, brevicin 925A, and construction of a shuttle vector for lactic acid bacteria and Escherichia coli. Microbiology 155:1726-1737

25. Sambrook J, Fritsch EF, Maniatis T (1989) Molecular cloning: a laboratory manual, 2nd edn. Cold Spring Harbor Laboratory Press, Cold Spring Harbor, New York

26. Yan TR, Wang MR, Chen CH (1998) A facile PCR method for detecting replication mode of lactococcial plasmids. Biotechnol Tech 12:85-89

27. Rodriguez MC, Alegre MT, Mesas JM (2007) Optimization of technical conditions for the transformation of Pediococcus acidilactici P60 by electroporation. Plasmid 58:44-50

28. Gravesen A, Josephsen J, von Wright A, Vogensen FK (1995) Characterization of the replicon from the lactococcal theta-replicating plasmid pJW563. Plasmid 34:105-118

29. Perez-Arellano I, Zuniga M, Perez-Martinez G (2001) Construction of compatible wide-host-range shuttle vectors for lactic acid bacteria and Escherichia coli. Plasmid 46:106-116

30. Tagg JR, Dajani AS, Wannamaker IW (1976) Bacteriocins of Gram-positive bacteria. Microbiol Rev 40:722-751

31. Sarkar PK, Banerjee S (1996) Antibacterial activity of lactic acid bacterial isolates obtained from natural habitats. J Food Sci Tec 33:231-233

32. Geoffroy MC, Guyard C, Quatannens B, Pavan S, Lange M, Mercenier A (2000) Use of green fluorescent protein to tag lactic acid bacterium strains under development as live vaccine vectors. Appl Environ Microbiol 66(1): 383-391

33. Dashkevicz MP, Feighner SD (1989) Development of a differential medium for bile salt hydrolase-active Lactobacillus spp. Appl Environ Microbiol 55:11-16

34. Liong MT, Shah NP (2005) Bile salt deconjugation ability, bile salt hydrolase activity and cholesterol co-precipitation ability of lactobacilli strains. Int Dairy J 15:391-398

35. Yin S, Zhai Z, Wang G, An H, Luo Y, Hao Y (2011) A novel vector for lactic acid bacteria that uses a bile salt hydrolase gene as a potential food-grade selection marker. J Biotechnol 152:49-53

36. Kumar R, Rajkumar H, Kumar M, Varikuti SR, Athimamula R, Shujauddin M, Ramagoni R, Kondapalli N (2013) Molecular cloning, characterization and heterologous expression of bile salt hydrolase (Bsh) from Lactobacillus fermentum NCDO394. Mol Biol Rep 40:5057-5066. https://doi.org/10.1007/ s1 1033-013-2607-2

37. Jiang J, Hang X, Zhang M, Liu X, Li D, Yang H (2010) Diversity of bile salt hydrolase activities in different lactobacilli toward human bile salts. Ann Microbiol 60:81-88. https://doi.org/10.1007/s13213-009-0004-9

38. Oosta GM, Mathewson NS, Catravas GN (1978) Optimization of folinciocalteu reagent concentration in an automated Lowry protein assay. Anal Biochem 89:31-34

39. Chang SM, Yan TR (2014) Genetic engineering techniques for lactic acid bacteria: construction of a stable shuttle vector and expression vector for $\beta$ glucuronidase. Biotechnol Lett 36(2):327-335

40. Dong Z, Zhang J, Lee B, Li H, Du G, Chen J (2012) A bile salt hydrolase gene of Lactobacillusplantarum BBE7 with high cholesterol-removing activity. Eur Food Res Technol 235:419-427. https://doi.org/10.1007/s00217-012-1769-9
41. Suzuki H, Yano H, Brown CJ, Top EM (2010) Predicting plasmid promiscuity based on genomic signature. J Bacteriol 192(22):6045-6055. https://doi.org/ 10.1128/JB.00277-10

42. del Solar G, Hernandez-Arriaga AM, Gomis-Ruth FX, Coll M, Espinosa M (2002) A genetically economical family of plasmid-encoded transcriptional repressors involved in control of plasmid copy number. J Bacteriol 184(18): 4943-4951. https://doi.org/10.1128/JB.184.18.4943-4951.2002

43. Froseth BR, McKay LL (1991) Molecular characterization of the nisin resistance region of Lactococcuslactis subsp. lactis biovar diacetylactis DRC3t Appl Environ Microbiol 57(3):804-811

44. Posno M, Leer RJ, van Luijk N, van Giezen MJF, Heuvelmans PTHM, Lokman BC, Pouwels PH (1991) Incompatibility of Lactobacillus vectors with replicons derived from small cryptic Lactobacillus plasmids and segregational instability of the introduced vectors. Appl Environ Microbiol 57:1822-1828

45. Allison GE, Klaenhammer TR (1996) Functional analysis of the gene encoding immunity to Lactacin F, lafl, and its use as a Lactobacillus-specific, food-grade genetic marker. Appl Environ Microbiol 62(12):4450-4460

46. Platteeuw C, van Alen-Boerrigter I, van Schalkwijk S, de Vos WM (1996) Food-grade cloning and expression system for Lactococcuslactis. Appl Environ Microbiol 62(3):1008-1013

47. Leenhouts K, Bolhuis A, Venema G, Kok J (1998) Construction of a foodgrade multiple-copy integration system for Lactococcuslactis. Appl Microbiol Biotechnol 49(4):417-423

48. Boucher I, Parrot M, Gaudreau H, Champagne CP, Vadeboncoeur C, Moineau S (2002) Novel food-grade plasmid vector based on melibiose fermentation for the genetic engineering of Lactococcus lactis. Appl Environ Microbiol 68:6152-6161

49. Sridhar V, Smeianov W, Steele JL (2006) Construction and evaluation of food-grade vectors for Lactococcuslactis using aspartate aminotransferase and a-galactosidase as selectable markers. J Appl Microbiol 101(1):161-171

50. Richards HA, Han CT, Hopkins RG, Failla ML, Ward WW, Stewart CN Jr (2003) Safety assessment of recombinant green fluorescent protein orally administered to weaned rats. J Nutr 133:1909-1912

51. Russo P, Iturria I, Mohedano ML, Caggianiello G, Rainieri S, Fiocco D et al (2015) Zebrafish gut colonization by mCherry-labelled lactic acid bacteria. Appl Microbiol Biotechnol 99:3479-3490

52. Shimizu-Kadota M, Shibahara-Sone H, Ishiwa H (1991) Shuttle plasmid vectors for Lactobacillus casei and Escherichia coli with a minus origin. Appl Environ Microbiol 57:3292-3300

53. Elkins CA, Moser SA, Savage DC (2001) Genes encoding bile salt hydrolases and conjugated bile salt transporters in Lactobacillusjohnsonii 100-100 and other Lactobacillus species. Microbiology 147:3403-3412

54. Kim GB, Mathieu B, Lee BH (2005) Cloning and characterization of a bile salt hydrolase (bsh) from Bifidobacterium adolescentis. Biotechnol Lett 27(12):817-822

55. Suresh CG, Pundle AV, SivaRaman H, Rao KN, Brannigan JA et al (1999) Penicillin $V$ acylase crystal structure reveals new Ntn-hydrolase family members. Nat Struct Biol 6:414-416

56. Oinonen C, Rouvinen J (2000) Structural comparison of Ntn-hydrolases. Protein Sci 9:2329-2337

57. Kim GB, Miyamoto CM, Meighen EA, Lee BH (2004) Cloning and characterization of the bile salt hydrolase genes (bsh) from Bifidobacterium bifidum strains. Appl Environ Microbiol 70(9):5603-5612. https://doi.org/10. 1128/AEM.70.9.5603-5612.2004

58. Begley M, Hill C, Gahan CGM (2006) Bile salt hydrolase activity inprobiotics. Appl Environ Microbiol 72:1729-1738

59. Lambert JM, Bongers RS, De Vos WM, Kleerebezem M (2008) Functional analysis of four bile salt hydrolase and penicillin acylase family members in Lactobacillus plantarum WCFS1. Appl Environ Microbiol 74:4719-4726

60. Balgir PP, Kaur B, Kaur T (2014) A preliminary clinical evaluation of probiotics Pediococcus acidilactici MTCC5101 and Bacillus coagulans MTCC492 on young anemic women. Int J Fermented Foods 3:45

61. Simonen M, Palva I (1993) Protein secretion in bacillus species. Microbiol Rev 57(1):109-137

62. van Asseldonk M, Rutten G, Oteman M, Siezen RJ, de Vos WM, Simons G (1990) Cloning of usp45, a gene encoding a secreted protein from Lactococcus lactis subsp. lactis MG1363. Gene 95:155-160

63. Ng DTW, Sarkar CA (2013) Engineering signal peptides for enhanced protein secretion from Lactococcuslactis. Appl Environl Microbiol 79(1):347-356

64. van Asseldonk M, de Vos WM, Simons G (1993) Functional analysis of the Lactococcus lactis Usp45 secretion signal in the secretion of a homologous proteinase and a heterologous a-amylase. Mol Gen Genet 240:428-434 
65. Steidler L, Hans W, Schotte L, Neirynck S, Obermeier F, Falk W et al (2000) Treatment of murine colitis by Lactococcuslactis secreting interleukin-10. Science 289(5483):1352-1355. https://doi.org/10.1128/AEM.02667-12

66. Le Loir Y, Nouaille S, Commissaire J, Bretigny L, Gruss A, Langella P (2001) Signal peptide and propeptide optimization for heterologous protein secretion in Lactococcus lactis. Appl Environ Microbiol 67:4119-4127

67. Xu S, Liu T, Radji CA, Yang J, Chen L (2016) Isolation, identification, and evaluation of new lactic acid bacteria strains with both cellular antioxidant and bile salt hydrolase activities in vitro. J Food Prot 79(11):1919-1928. https://doi.org/10.4315/0362-028X.JFP-16-096

68. O'Flaherty S, Briner Crawley A, Theriot CM, Barrangou R (2018) The Lactobacillus bile salt hydrolase repertoire reveals niche-specific adaptation. mSphere 3:e00140-e00118. https://doi.org/10.1128/mSphere.00140-18

69. Brashears MM, Gilliland SE, Buck LM (1998) Bile salt deconjugation and cholesterol removal from media by Lactobacillus casei. J Dairy Sci 81(8): 2103-2110

70. Coleman JP, Hudson LL (1995) Cloning and characterization of a conjugated bile acid hydrolase gene from Clostridiumperfringens. ApplEnvironMicrobiol 61(7):2514-2520

71. Tanaka H, Hashiba H, Kok J, Mierau I (2000) Bile salt hydrolase of Bifidobacterium longum-biochemical and genetic characterization. Appl Environ Microbiol 66(6):2502-2512

72. Yuksekdag ZN, Aslim B (2010) Assessment of potential probiotic and starter properties of Pediococcus spp. isolated from Turkish-type fermented sausages (Sucuk). J Microbiol Biotechnol 20:161-168. https://doi.org/10. 4014/jmb.0904.04019

73. Ruiz-Moyano S, Martin A, Benito MJ, Hernandez A, Casquete R, de Guia CM (2011) Application of Lactobacillus fermentum HL57 and Pediococcus acidilactici SP979 as potential probiotics in the manufacture of traditional Iberian dry-fermented sausages. Food Microbiol 28(5):839-847

74. Ribeiro MCO, de Souza Vandenberghe LP, Spier MR, Paludo KS, Soccol CR, Soccol VT (2014) Evaluation of probiotic properties of Pediococcus acidilactici B14 in association with Lactobacillus acidophilus ATCC 4356 for application in a soy based aerated symbiotic dessert. Brazilian Arch Biol Technol 57(5): 755-765

\section{Publisher's Note}

Springer Nature remains neutral with regard to jurisdictional claims in published maps and institutional affiliations.

\section{Submit your manuscript to a SpringerOpen ${ }^{\circ}$ journal and benefit from:}

- Convenient online submission

- Rigorous peer review

- Open access: articles freely available online

- High visibility within the field

- Retaining the copyright to your article

Submit your next manuscript at $\boldsymbol{\nabla}$ springeropen.com 